\title{
On the Interpretation of Fossil Nuclei
}

\author{
Xin Wang \\ State Key Laboratory of Palaeobiology and Stratigraphy, Nanjing Institute of Geology and Palaeontology, CAS, \\ Nanjing, China \\ Email: xinwang@nigpas.ac.cn
}

Received 28 January 2016; accepted 3 May 2016; published 6 May 2016

Copyright (C) 2016 by author and Scientific Research Publishing Inc.

This work is licensed under the Creative Commons Attribution International License (CC BY).

http://creativecommons.org/licenses/by/4.0/

(c) (i) Open Access

\begin{abstract}
Although organelle preservation in plant fossils is not novel and well-preserved plant mesofossils have contributed greatly to the understanding of plant evolution, subcellular structures are still a rarity in plant mesofossils. Although it is not easy to explore subcellular structures in plant fossils, related attempts are frequently seen. Among them, some false interpretation requires further inspection. To shed more light on this issue, here I studied Cretaceous charcoalified mesofossils from USA, using LM (light microscopy), SEM (scanning electron microscopy) and TEM (transmission electron microscopy) technologies. My conclusion shows that not all publications reflect the truthful existence of nuclei in plant fossils, and this study may provide a reference for the future research.
\end{abstract}

\section{Keywords}

Fossil, Nuclei, Cell, Plant, Misinterpretation

\section{Introduction}

In the studies of plant fossils, the exploration of nuclei is a difficult spot [1]-[5]. Some researchers have published excellent papers regarding this aspect [2]-[5]. Recently Friis et al. [1] also reported nuclei in exquisite Early Cretaceous fossil seeds. Although their main conclusion that herbs are among early angiosperms is an old idea dated back to 1960s [1] and is supported by recent discovery of Jurassic herbaceous plant [6], their claim of nuclei deserves further scrutiny. Here, to shed more light on this issue, some plant mesofossils from the AlbianCenomanian (Cretaceous) of Kansas, USA, were studied using LM, SEM and TEM [7] [8].

\section{Materials and Methods}

The materials were collected from the Dakota Formation outcrop near Black Wolf, Ellsworth, Kansas, USA $\left(38^{\circ} 43^{\prime} 91^{\prime \prime} \mathrm{N}, 98^{\circ} 22^{\prime} 17^{\prime \prime} \mathrm{W}\right)$. The collected samples were digested in running water for a week at room temperature, 
flushed and sieved using USA Standard Testing Sieve No. 35 (32 mesh, with a mesh size of $0.5 \mathrm{~mm}$ ), air-dried, and picked under a stereomicroscope. Selected specimens were cleaned with HF, mounted on SEM stubs, coated with gold, and observed using SEM. One of the specimens were processed with nitric acid, cleaned, and then embedded in paraffin and cut into serial sections for LM observation, following the procedure used for living plant materials. Some of these sections were mounted on SEM stubs for further observation. To compare fossil and extant plant materials, I baked leaves of Ligustrum japonicum trees from the Diamond Village, University of Florida, or set such leaves on fire. The leaf materials that became charred after these procedures were prepared for LM, SEM, and TEM as described for the fossil materials above. The such-processed materials were embedded in Epon resin, cut into ultrathin sections, and stained for TEM observation. (More details can be found in previous works [7] [8]).

\section{Results}

A charcoalified shoot apex with at least two lateral appendages (UF15719-44149) is preserved in three dimensions (Figure 1(a)). The preservation allows detailed anatomical observation (Figure 1(b), Figure 1(c)). In nearly all cell lumina contained are cell residues (Figures 1(a)-(d)). These cell residues are spiny in form and remain connected to the cell walls through thin strands (Figures 1(c)-(e)). A similar configuration is observed in better preserved cell of another fossil (UF15719-44457). Similar spiny cell configurations are also observed in baked parenchymatous cells (Figure 1(g)) and half-burned cells (Figure 1(h)) of extant Ligustrum japonicum.

\section{Discussion}

Questions In this study, I have observed the spiny cell residues in preserved cells of fossil plants and paren-
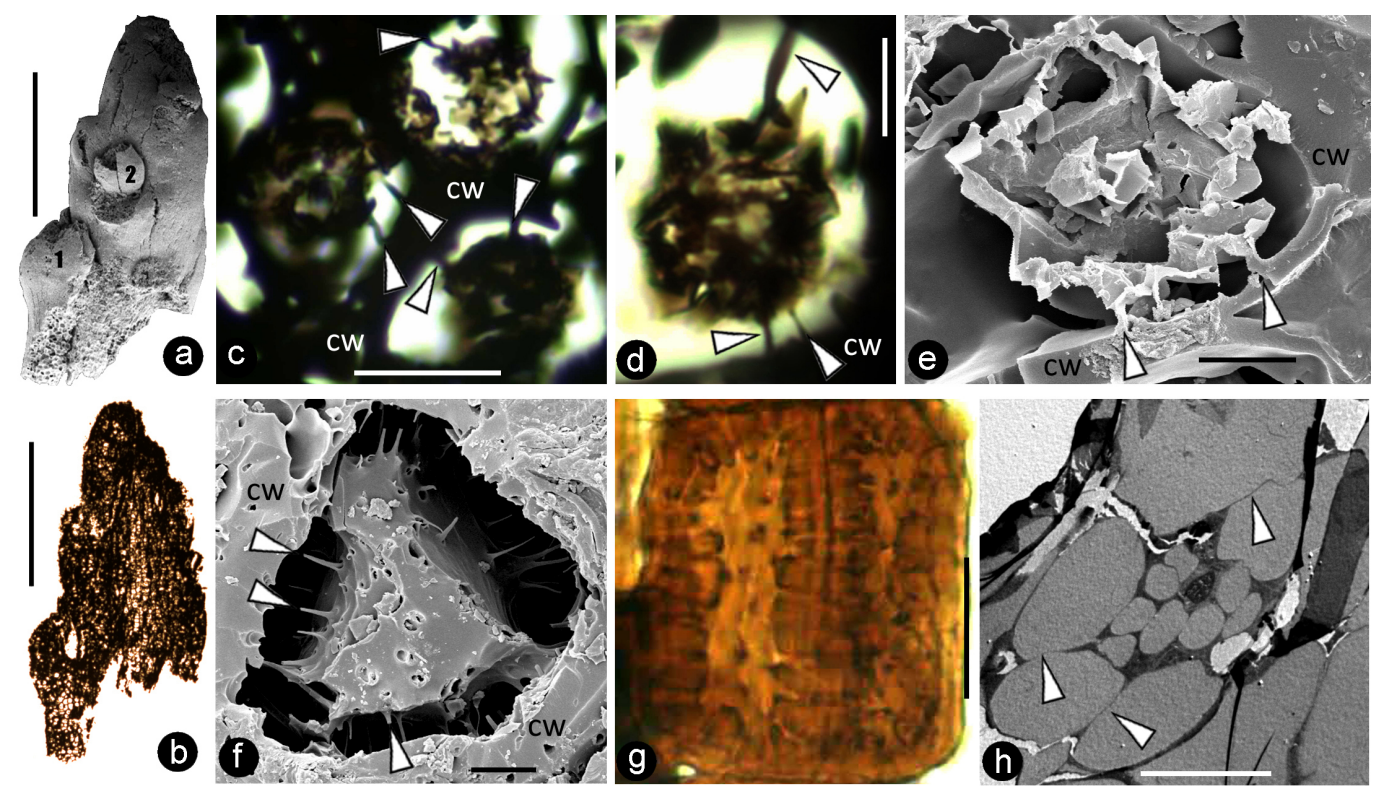

Figure 1. Fossil and extant plant with spiny cell residues. (a) SEM image of an Albian-Cenomanian shoot apex (Yiruia membranacea) from Black Wolf, Ellsworth, Kansas, USA [8]. Note the two appendages $(1,2)$ on it. Deposited in the Florida Museum of Natural History. Specimen number UF15719-44149. Reproduced from [7]. Bar = $1 \mathrm{~mm}$. (b) Longitudinal paraffin section of the specimen shown in Figure 1(a). LM. Bar $=1 \mathrm{~mm}$. (c) Portion of the section shown in Figure 1(b), showing several shrunken cells still attached (arrows) to the cell walls (cw). LM. Reproduced from [7]. Bar $=20 \mu \mathrm{m}$. (d) Detailed view of one of such cells showing an angular central body connected to the cell wall (cw) by spine-like structures (arrows). LM. Reproduced from [7]. Bar $=10 \mu \mathrm{m}$. (e) SEM view of one of such cells cut open, showing the spatial relationship between the central body with angular surface and its connections (arrows) to the cell wall (cw). Bar $=5 \mu$ m. (f) A shrunken cell with a central cell body and spine-like structures (arrows) that connect it with the cell wall (cw). Reproduced from [7]. Bar $=10 \mu \mathrm{m}$. (g) Two adjacent baked parenchymatic cells of extant Ligustrum japonicum with spiny-configured cells. LM. Reproduced from [7]. Bar $=20 \mu \mathrm{m}$. (h) A half-burned parenchymatic cell of extant Ligustrum japonicum with spiny configuration. Note the thin cytoplasm strands (arrows), spongy cytoplasm in the centre, and nucleus (dark oval body in the cell). TEM. Reproduced from [7]. $\mathrm{Bar}=10 \mu \mathrm{m}$. 
chymatous cells of an extant plant. These cell residues demonstrate great resemblance to the nuclei claimed by Friis et al. [1], implying that they may have mistakenly taken such cell relicts as nuclei. Before accepting their claim, the following questions have to be answered. First, there is no known rational explanation in cell biology that nuclei can be preferentially preserved, whereas other organelles and cytoplasm disappear completely. Why were the nuclei preserved in their case? Second, the nuclei in previous reported fossils, as well as extant plant cells, are all oval-shaped with smooth outlines, not spiny and connected to the cell walls through spine-like structures. Enlarging Figure 2(b) of Friis et al. [1] reveals that their presumed nuclei are actually spiny and connected to the cell walls through spine-like structures. What is underlying mechanism for the transition of the oval-shaped nuclei into a spiny one? Third, Niklas et al. have proven that nuclei are the most labile organelles that are preferentially destroyed (not preserved) in fossil plant cells, and this conclusion is based on statistics of thousands of cells in plant fossils [9] [10]. Why did the nuclei in the plant fossils in these studies [1] vs [9] [10] behave in such contrary ways?

Interpretation It is well known in cell biology that cells may become plasmolysed when they lose water, and plasmolysed cells remain connected to each other through plasmodesmata on cell walls, giving rise to a spiny configuration for the cells (Figure 5.19 of [11]; Web Figure 3.8.a of [12]). The spiny configuration of the presumed nuclei in Friis et al.' material is reminiscent of the plasmolysed cells observed in other Cretaceous fossil materials (Figures 1(b)-(d), Figure 1(f)) [7]. This interpretation of fossil phenomenon has been confirmed by simulation experiments using extant plant material: the parenchymatous cells of Ligustrum japonicum show a similar spiny cell configuration when the tissues are baked in an oven (Figure 1(g)) or half-burned in flame (Figure 1(h)). The great resemblance between spiny cells in both fossil and extant plant materials indicates that the nuclei or nuclei-related structures in Friis et al.'s paper may have little to do with nuclei. Therefore, a claim of nuclei in such plant fossils seems to require extra caution in the future.

\section{Conclusion}

This study indicates that recent claim of nuclei in plant fossils is false or at least tentative. Some cell residues in plant fossils may easily mislead researchers to take them as nuclei. I wish this work may provide a reference for better and accurate determination of fossil nuclei in future studies.

\section{Acknowledgements}

This research is supported by the National Basic Research Program of China (973 Program 2012CB821901), and National Natural Science Foundation of China (91514302, 91114201). This is a contribution to UNESCO IGCP632.

\section{References}

[1] Friis, E.M., Crane, P.R., Pedersen, K.R., Stampanoni, M. and Marone, F. (2015) Exceptional Preservation of Tiny Embryos Documents Seed Dormancy in Early Angiosperms. Nature, 528, 551-554. http://dx.doi.org/10.1038/nature16441

[2] Niklas, K.J., Brown, R.M., Santos, R. and Vian, B. (1978) Ultrastructure and Cytochemistry of Miocene Angiosperm Leaf Tissues. Proceedings of National Academy of Sciences USA, 75, 3263-3267. http://dx.doi.org/10.1073/pnas.75.7.3263

[3] Poinar, H.N., Melzer, R.R. and Poinar, G.O. (1996) Ultrastructure of 30-40 Million Year Old Leaflets from Dominican Amber (Hymenaea protera, Fabaceae: Angiospermae). Experimentia, 52, 387-390. http://dx.doi.org/10.1007/BF01919546

[4] Schönhut, K., Vann, D.R. and LePage, B.A. (2004) Cytological and Ultrastructural Preservations in Eocene Metasequoia Leaves from the Canadian High Arctic. American Journal of Botany, 91, 816-824. http://dx.doi.org/10.3732/ajb.91.6.816

[5] Ozerov, I.A., Zhinkina, N.A., Efimov, A.M., Machs, E.M. and Rodionov, A.V. (2006) Feulgen-Positive Staining of the Cell Nuclei in Fossilized Leaf and Fruit Tissues of the Lower Eocene Myrtaceae. Botanical Journal of Linnean Society, 150, 315-321. http://dx.doi.org/10.1111/j.1095-8339.2006.00471.x

[6] Han, G., Liu, Z.-J., Liu, X., Mao, L., Jacques, F.M.B. and Wang, X. (2016) A Whole Plant Herbaceous Angiosperm from the Middle Jurassic of China. Acta Geologica Sinica (English Edition), 90, 19-29. http://dx.doi.org/10.1111/1755-6724.12592 
[7] Wang, X. (2007) High Temperature as a Mechanism for Plant Cytoplasm Preservation in Fossils. Acta Geologica Sinica (English Edition), 81, 183-193. http://dx.doi.org/10.1111/j.1755-6724.2007.tb00943.X

[8] Wang, X. (2004) A Study of Plant Mesofossils from the Dakota Formation in Kansas, USA. Ph.D. Dissertation, University of Florida, Gainesville.

[9] Niklas, K.J. and Giannasi, D.E. (Smiley, C.J., Ed.) (1985) Late Cenozoic History of the Pacific Northwest. AAAS Pacific Division, Ashland, 175-183.

[10] Niklas, K.J. (1982) Differential Preservation of Protoplasm in Fossil Angiosperm Leaf Tissues. American Journal of Botany, 69, 325-334. http://dx.doi.org/10.2307/2443136

[11] Oldroyd, H. (1969) Plant Cells, an Introduction to Plant Protoplasm. McGraw-Hill Book Company, New York.

[12] Taiz, L. Zeiger, E., Møller, I.M. and Murphy, A. (2015) Plant Physiology and Development. 6th Edition, Sinauer Associates, Sunderland, CT. 